\title{
Vegetation Database of Dry Grasslands in the Southeast Romania
}

\author{
Claudia Bita-Nicolae
}

\begin{abstract}
In this short database report information of a vegetation database on dry grasslands and related communities from the Southeast Romania is presented. It includes 513 synoptic tables and 2,500 relevés of Koelerio-Corynephoretea (Sedo-Scleranthetea, Festucetea vaginatae), Festuco-Brometea, Trifolio-Geranietea sanguinei, Elyno-Seslerietea (Seslerietea albicantis, Kobresio myosuroidis-Seslerietea caerulea). Additionally there is an estimated total of 6,000 relevés in the studied territory from literature (Romanian literature especially) since 1940 to present. This report describes the available content in the Vegetation Database of Dry Grasslands in the Southeast Romania (GIVD ID EU-RO-001).
\end{abstract}

Keywords: grassland; relevé; Romania.

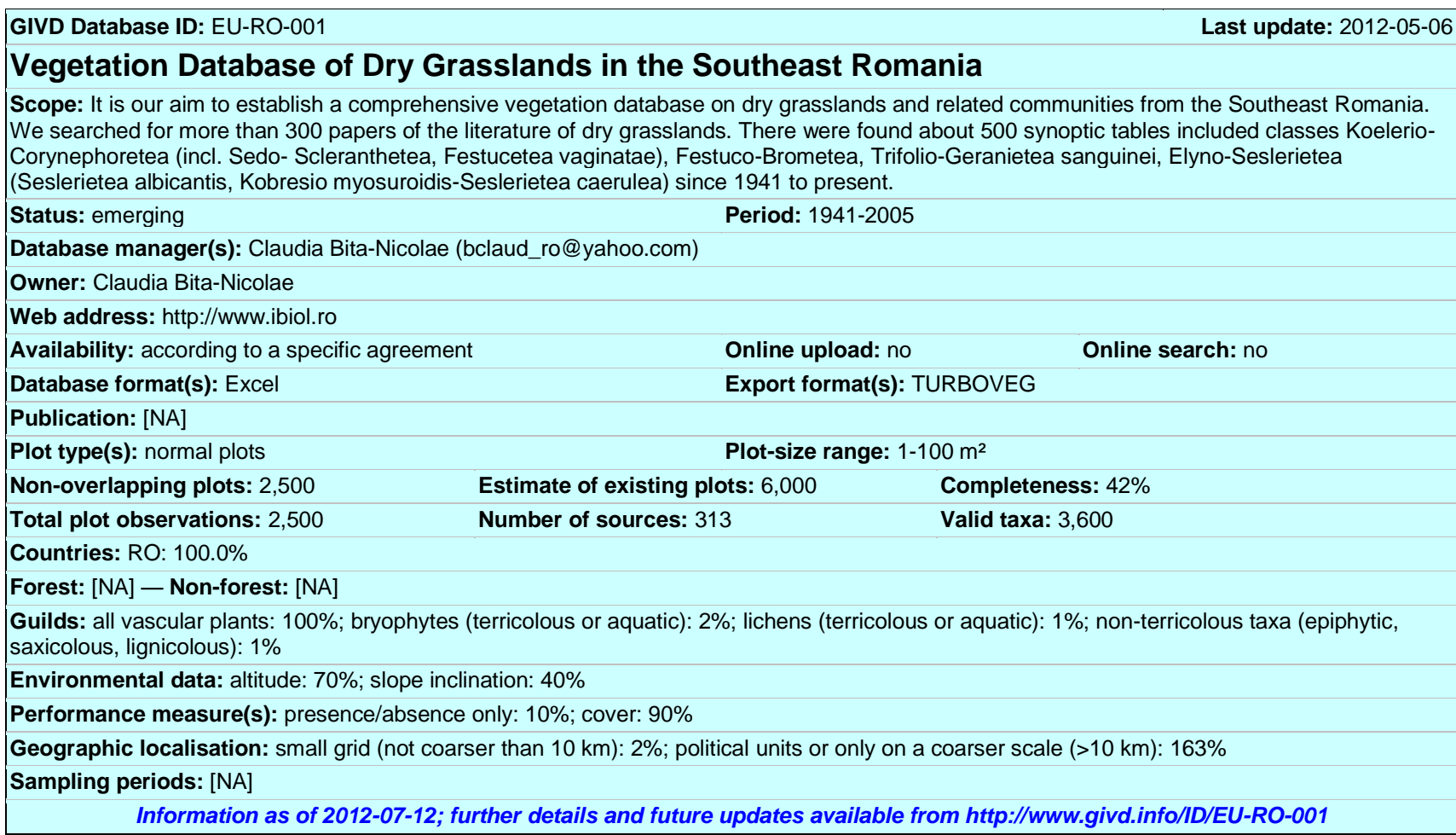

Claudia Bita-Nicolae (bclaud_ro@yahoo.com)

Institute of Biology, Romanian Academy, 296 Spl. Independentei, 060031 Bucharest, ROMANIA 